\title{
DISCOVERING SIGNIFICANT PECULIARITIES OF PEDAGOGICAL CONFLICT: THEORETICAL ASPECT
}

\section{G. Polishchuk}

The article deals with the generalization of the points of view of scientists on the essence of the notions "conflict", "pedagogical conflict" depending on their scientific approach for investigation. The integrative approach to the definition of these notions that unites into a single whole several other approaches (situational, personal, and motivational) was analyzed. Different approaches of scientists were examined as for the typology of conflicts. It has been estimated, that in the scope of pedagogy different classifications of conflicts are available where the content, importance, the sphere, duration of conflicts, direction, character of appearance, the structure of relationships, consequences, functions, socio-psychological effects, social results are taken into consideration. It is assumed, that the notion of pedagogical conflict includes different forms and methods of contradiction, tension in relations, explicit and hidden struggle. The functions of pedagogical conflicts in regulating interpersonal and intergroup relations were focused on (positive, negative); the reasons of pedagogical conflicts in high educational establishments (socio-economic, socio-psychological, psychological, organizationalpedagogical); the direction of the development of conflictological competence of a teacher (age and individual peculiarities of pupils, self-control of teacher's behavior, the knowledge of pupils' psychology and modern methods of teaching and upbringing of pupils)

Keywords: conflict, pedagogical conflict, conflict situations, typology of conflicts, conflictological competence, regulation of relationships

\section{Introduction}

Following a steady growth of scholarly interest and activity over the past several years (2000-2020), conflictology has now become the major field of pure and applied research for scholars in the former Soviet Union and other countries of Western Europe. Its coming of age has been marked by a number of international conferences, while its acknowledged importance is reflected in several large scale research projects which have conflictology as their principal focus of interest.

\section{Literature review}

Recognition of conflictilogy as an important contemporary issue within pedagogy and psychology is proved by widespread research activity, but also by the publications of several dissertations, reflecting one theoretical perspective or another, and by the attention, increasingly given to the subject in scientific articles on the typology of conflicts, nature of conflicts, and the availability of monographs, devoted to conflictology. For instance, a consideration of psychological prophylactics of conflicts in high educational establishments was given by Soroka [1] with the main emphasis on the stages of conflict: the beginning of conflict, the development of conflict, climax and denouement. In the work by Kozich [2] special attention was paid to the formation of conflictological competence of teachers in secondary schools and the reasons of conflicts in the pedagogical environment, such as social reasons, psychological reasons, pedagogical etc., were carefully investigated. Conlfictological competence as the major factor of cooperation in schools was analyzed by Plachotna [3] paying attention to the peculiarities of conflict resolution methods in a pedagogical establishment. Conflict as the process, having 5 main stages in its development, such as the appearance of a conflict situation, the understanding of a conflict situation, the realization of a conflict behavior, the deepening of a conflict situation and its resolution was in the scope of attention of Aleksandrova and Munshi [4]. Several academic publications [5-7] in the field of conflictology among foreign researchers highlight the importance of investigation of conflict management strategies, the leadership qualities to manage conflicts effectively and become a conflict competent leader.

Yet, despite the existence of authoritative research papers, there is to date no book-length account of pedagogical conflicts of the various theoretical currents, which inform present-day pedagogical studies, nor one, which takes account of the associated disciplines, such as social studies, psychology etc., to which those studies are making such a vital contribution.

\section{The aim and objectives of the study}

Thus, the aim of this study is to present a systematic research of definitions of conflicts, in particular pedagogical conflicts, from the viewpoint of their theoretical point-by-point description. Although they are, and have long been, a popular topic in pedagogy and psychology, there is, as far as our investigation is concerned, neither universally accepted formal definition of pedagogical conflict nor a proposal for their uniform and systematic treatment in scientific literature.

To accomplish that aim, the following tasks have been set: 
1. To present theoretical survey of the existing approaches to the definition of conflicts;

2. To characterize and define the reasons of pedagogical conflicts;

3. To reveal the peculiarities of the nature of conflict;

4. To clear out the typology of conflicts and substantiate possible ways of guiding conflicts in the field of high educational establishments.

\section{Materials and Methods}

The following theoretical methods to attain the purpose of the study and solve particular tasks are used: comparative analyses of scientific literature to study the essence of the phenomenon "conflict" and characterize and define the reasons of pedagogical conflicts; synthesis of theoretical data to reveal the nature of conflict; analysis and comparison of scientific concepts on the typology of conflicts; method of generalization to substantiate possible ways of guiding conflicts in the field of high educational establishments.

Conflicts (from Latin conflictus - collision, clash of interests) - no matter how one understands them, are known as active disagreement between people with opposing opinions or principles; fighting between two or more groups of people or countries, they have to be defined in terms of their importance for contemporary pedagogy. This establishes our course: first, conflicts in general would be defined, then a typology of conflicts would be proposed; finally, the place of pedagogical conflicts, which they occupy among other conflicts in the sphere of education and their role in society, would be pointed out.

\section{Result}

Social and political clashes, industrial revolutions, ethnic and racial discrimination, family disagreements bring people into conflicts. More than that: many of these matters are areas of serious conflicts in society. Following T.Branitska, young people are especially vulnerable to the destructive power of social, political and economic factors and among youngsters radical views are formed rapidly. That is why teenagers and young people are often characterized as being intolerant, aggressive and able to lose self-control. Low level of empathy may contribute to conflict in social interactions and thereby heighten levels of negative emotions, experienced by young people. Educational establishments have to be able to guide conflicts, taking advance measures for conflict resolution [8]. A contemporary teacher should be aware of conflict management, be able to reduce tension and minimize different conflicting areas in the process of educating young people. Foreign language teachers occupy a special place in the successful treatment of resolving conflicts, as they speak not only their native language, but also foreign, and are always ready to interact with different cultures, people of different nationalities and find common ground with them.

Social and psychological aspects of conflictology have been investigated by many scientists and following G.Antonov, at the contemporary stage of the development of conflictology, there is no accepted definition of conflict and in scientific literature conflicts are characterized mainly by different aspects: interpersonal and inter- active antagonisms; reaction of people to certain incompatible points: competitions, clashes, oppositeness of interests, debates, principles, opinions, essential lack of tolerance, ignorance of smb's beliefs, positions, disregarding wishes of other people or complete humiliation and loss of honour [9].

M. Truchan has been of the same opinion and proves that every author investigates conflicts from different points of view, but in the majority of cases, there is a huge literature about what causes conflicts and certainly, ways of conflict resolution are taken into consideration: continuation of long-lasting disagreements, contradictory judgments, opposing ideas, etc. The author underlines that this approach is widely used in General Pedagogy and Psychology, Medicine, Social Psychology, Psychotherapy, Social Studies, Politology etc. It is obvious, that each of these disciplines highlights conflict from its perspectives [10].

We cannot but agree with I. Glazkova's [11] opinion that investigation of the role of conflicts in the life of people and society is the domain of Psychology and Social Studies, but at the same time scientists (O. Belkin, V. Zhavoronkov, O. Ionova and others) underline that nowadays it is crucial to explore the pedagogical aspect of conflict otherwise, the very essence of conflictology is lowered and has no impact on the conflict potential of educational surrounding and society life. Thus, the pedagogical aspect of conflictology must be systematized and given relevant description at the contemporary development of Ukrainian society.

As was mentioned before, the goals of this article grew out of three basic areas of concern and interest, several factors of conflict interaction, suggested by $\mathrm{V}$. Lincoln [12], have to be taken into consideration for our further practical investigation of pedagogical conflicts:

informational factors, which appear due to disability of one of participants to perceive certain information that may cause a conflict situation: gossips, temporary disinformation, unreliability of informational resources, experts, witnesses; non-accuracy of translation/interpretation of some news in mass media, announcement of confidential information;

behavioral factors, characterizing the peculiarities of behavior of conflict participants: impudence, egoism, ambitions, loss of honour, violation of certain demands, continuous determined opposition, manipulation etc;

attitudinal factors, characterized by absence of satisfaction of interpersonal interaction between participants: conflicting interests, views; different educational and cultural level, lack of confidence, negative experience of participants of a conflict;

evaluative factors, characterized by opposing religious, political persuasions, cultural beliefs and principles. This approach may be treated as integrative as it unites several other approaches (situational, interpersonal, motivational and others).

Examination of the material (M. Bashkin, N. Volkova, A. Girnik, K. Levin, O. Rilska etc) also provides evidence of the diversity of points of view on the typology of conflicts. Most scientists agree that it is best to describe conflicts in terms of the quality of participants, differentiating between intrapersonal, interpersonal, intergroup conflicts. M.Bashkin proves that conflicts 
may by described from the point of their orientation: horizontal, vertical and mixed; their consequences: constructive and destructive; reasons of conflicts: objective and subjective; sphere of their resolution: official and emotional, etc. [13].

Further important distinctions were drawn within the terms of duration of conflicts: short lasting, long lasting and protracted; character of conflict course: open (visible and deep-rooted), surface (visible, but shallow with no roots), latent (below the surface with potential to emerge), acute conflict and chronic conflict; character of conflicts: spontaneous and planned (started on purpose); nature of conflict resolution: those, spontaneously stopped, those, ceased under the influence of methods, suggested by conflict participants, and those, regulated by the influence of outer circumstances; level of regulation: controlled, non-controlled and partly controlled; criteria of truth/falsity: real conflicts, conventional conflicts, false and mixed conflicts. Discussing the typology of conflicts, it has also been stated, that conflicts may be examined due to the spheres of their course: international, economic, political, labour, religious, environmental etc. The author proves that different types of conflicts are interconnected and can be mutually dependent [14].

To gain a deeper insight into the typology of conflicts, N.Volkova's classification must be taken into consideration. Different conflict situations are examined according to their main peculiarities: manner of interaction: interpersonal, intergroup, international, intergender, intrapersonal: peculiarities of their manifestation: open (that are easily recognized), latent (that are recognized only by indirect signs); types of resolution: complicated and non-complicated; character of conflicts: real coming out of existing reasons, unreal coming out of emotional outbursts having no objective reasons; result: productive and non-productive; character of influence: constructive, stabilizing, destructive that can only deepen a conflict situation and violate norms and rules; direction of communication: vertical (boss-subordinate) and horizontal (boss-boss, subordinate-subordinate); the number of people, engaged in conflict: pair, local, general [15].

On the whole most scientist agree that it is best to classify conflicts in terms of their content, importance, duration, character of appearance and resolution, consequences and functions, sociopsychological effects, etc. This diversity gives no opportunity for scientists to work out the unified classification of conflicts. Psychological difficulty and versatility of the notion of conflict enables the researches to choose different criteria for its analyses and description.

The notion of pedagogical conflict is especially fruitful for our research. Different aspects of conflict resolution have been examined and the following definition of pedagogical conflict was suggested by G. Antonov: the sharp way of the development and resolution of essential discrepancies between participants of the pedagogical process, accompanied by negative emotions that must be successfully resolved and harmonized [9].

Examination of the material also provides evidence of pedagogical conflict as consisting of different forms of opposing views and principles, emotional tension, and hidden and open ways of conflict resolutions. The most general definition of pedagogical conflict is the following: disagreement, clashes between people, owing to a difference in motives, points of view, under the circumstances of profound disagreement from both sides of a conflict. The basis of such conflicts is the essential lack of harmony, providing antagonism. Modern conflictology defines conflict through discrepancies and I. Nikulina focuses on dialectal and causal contradictions as the primary reasons of pedagogical conflicts. Dialectal are characteristic of a pedagogical system, causal are characteristic of professional incompetence of teachers. Especially interesting are the proves that pedagogical conflicts are the primary sources of the educational process development as the positive conflict resolution adds much to the personal growth of the participants of the conflict [16].

Without realizing the real reasons of a conflict between students and teachers, students and students, administration and subordinates in the system of high education, it is possible to tighten the conflict with different negative consequences. It is understood, that personal psychological peculiarities of participants of the educational process create certain conditions for conflict situations among different categories of employees of educational establishments, thus illustrating the conflict potential of every pedagogical process [17]. Further important distinctions were drawn within three levels of interaction of participants in high school: macrolevel (society - educational establishment), mesolevel (rector administration teachers) and microlevel (student - teacher, teacher teacher, student - student). Especially interesting are the results of N.Pitbutska's investigation: the majority of conflicts in high school are those among students and teachers because students often do not want to obey teachers and are sure that teachers impose burdens they cannot endure [18]. Positive conflict resolution helps to gain experience for ones rights defense at different levels. Thus, conflicts perform different functions in successful regulation of interpersonal and intergroup relations.

A careful examination of scientific works permitted M. Truhan to single out the following positive functions of professional conflicts in educational surrounding: developing function that helps to broaden the outlook of conflicting sides, leading to gaining certain social experience; mobilizing function that helps to mobilize efforts of people to resolve conflict situations; cognitive function warning conflicting sides about complex relationships that may appear; structural function that helps to differentiate certain social groups; instrumental function that helps to resolve tension due to successful conflict resolution; function of stimulating personal growth that helps to increase the sense of responsibility for one's words and deeds; psychotherapy and relieving function, helping to lessen stress and have the outburst of negative emotions; diagnosis function, throwing light on plus sides and drawbacks of participants of conflict situations.

Negative functions of professional conflicts were described as the following: the ruination of psychological climate among all participants of a conflict situation and their interpersonal relationships; the decrease of productivity; the complications of cooperation and limitation of partnership in the course of conflict and after it; increase of confrontation, leading to struggle instead of searching for alternative ways of conflict resolution [10]. 
Another important issue of conflictology is the analysis of the reasons of pedagogical conflicts that were grouped into social (the absence of socio-economic stability, low level of salaries, loss of prestige of the profession of a teacher); psychological (the peculiarities of age psychology, generation gap, psychological fatigue of teachers, behavioral peculiarities of students and teenagers, high or low degree of self-esteem etc.); pedagogical (low level of pedagogical culture, general errors in the methods of teaching, stereotyped estimation of student's activity, the absence of individual pedagogical position etc.) [2]

The reasons of pedagogical conflicts were raised by I. Nikulina from the point of view of teachers and students in the system of high education. Therefore, students are convinced that the primary reason of pedagogical conflicts is the absence of objective knowledge assessment and authoritarian attitude of teachers. Further important distinctions were drawn within the level of conflict potential of teachers, teachers with a high level of conflict potential and zero level of conflict potential that are fundamentally different. Students describe nonconflicting teachers as respectful, tolerant, having strong conflict resolution skills. It has to be underlined, that personal peculiarities of teachers may also lead to conflict situations as error in the choice of profession, lack of authority among students and colleagues, strong responsibility for the level of education etc.

On the contrary, discussing the reasons of conflicts, teachers are convinced that the major reasons are the following: lack of definite knowledge, intentional violation of set rules of behavior in the university, laziness, absence of desire to study, lack of respect etc. [19].

Taking into consideration the said above, the reasons of pedagogical conflicts depend on objective (outer conditions) and subjective (personal peculiarities) factors and may be grouped as socio-economic reasons connected, with an economic situation within the country; sociopsychological, connected with psychological fatigue and nervous routine of teachers; psychological, connected with different and often opposing interests, values, views etc.; pedagogical, connected with drawbacks in organization of the educational process and low level of conflictological culture, non-intelligibility in conflict management and conflict resolution skills. Thus, pedagogical conflict is a complex phenomenon, where different social, psychological, pedagogical, and personal factors are combined and exert influence on teachers as well as on students. We fully agree that it is best to describe pedagogical conflicts in terms of the basic peculiarities of their nature: different social status of the participants (student/teacher) defines different behavior; different degree of life experience and age, level of responsibility; different level of understanding of people and situations and sound judgment in dealing with them; different in capacity of reaching wise decisions or just conclusions; different level of mental rationalism etc. [20].

It is already widely accepted, that if it is impossible to avoid pedagogical conflicts, it would be reasonable to be able to recognize the beginning of it due to certain signals: crises, misunderstanding, incidents, fear etc. [21]. These signals usually demonstrate that a conflict situation really exists and must be resolved with the help of individual work with teachers and students. Different methods are preferable here for successful conflict resolution from good advice to administrative intrusion.

Each pedagogical conflict needs fruitful ways of its resolution, thus in our view the conception of $\mathrm{S}$. Plakhotna is extremely valuable: the responsibility of a teacher for correct conflict resolution, because educational establishments can be compared with a society model, where students get to know the norms of interaction between people; participants of a conflict situation have different social status leading to different behavior; different life experience of participants demonstrates different level of responsibility for mistakes, while resolving a conflict situation; the presence of other students, involved in a conflict, adds the flavor of demonstrational upbringing; the professional position of a teacher has to be primary in taking the initiative in conflict resolution and students' interests must be more important for him/her than his/her own; any mistake of a teacher may lead to new conflicts with new participants [3].

Thus, any conflict may be viewed as the process having five important steps: the beginning of a conflict situation, its mental realization by participants, the demonstration of conflict behavior, the deepening of a conflict and its resolution. The following points for conflict regulation were substantiated in contemporary conflictology: prediction and prevention of conflicts that will help to discover real conflict situations and due to high conflictological competence will solve misunderstandings without the open development stage of a conflict; warning of conflicts; creation of the professional system of mediation in conflict management; formation of conflict competence [22].

Discussing this issue, scientists agree that teachers in high educational establishments demonstrate low level of conflict and communicative competence and suggest creating certain conditions for minimization of factors, causing the appearance of pedagogical conflicts. Thus, a teacher has to be able to consider age and individual peculiarities of students, to control personal emotions i.e. to guide his/her emotional self-regulation [23].

\section{Conclusions}

We are now ready to generalize our results and make the following conclusions:

1. Conflicts are characterized by the following aspects: interpersonal and interactive antagonisms; reaction of people to certain incompatible points: competitions, clashes, oppositeness of interests, debates, principles, opinions, essential lack of tolerance, ignorance of smb's beliefs, positions, disregarding wishes of other people or complete humiliation and loss of honour. Conflicts are best described in terms of the quality of participants: intrapersonal, interpersonal, intergroup conflicts; from the point of their orientation: horizontal, vertical and mixed; their consequences: constructive and destructive; reasons of conflicts: objective and subjective; sphere of their resolution: official and emotional, etc.

2. The main reasons of pedagogical conflicts are: social, psychological, pedagogical.

3. Pedagogical conflicts are analyzed in terms of the basic peculiarities of their nature: different social status of participants (student/teacher) defines different 
behavior; different degree of life experience and age, level of responsibility; different level of understanding of people and situations and sound judgment in dealing with them; different in capacity of reaching wise decisions or just conclusions; different level of mental rationalism etc.; distinctions were drawn within the terms of duration of conflicts: short lasting, long lasting and protracted; character of conflict course: open, surface, latent, acute conflict and chronic conflict; character of conflicts: spontaneous and planned; nature of conflict resolution: those, spontaneously stopped, those ceased under the influence of methods found by conflict participants, and those, regulated by the influence of outer circumstances; level of regulation: controlled, non-controlled and partly controlled; criteria of truth/falsity: real conflicts, conventional conflicts, false and mixed conflicts.

4. Each pedagogical conflict needs fruitful ways of its resolution: the responsibility of a teacher for correct conflict resolution as students should get to know the norms of interaction between people; participants of a conflict situation have different social status, leading to different behavior; different life experience of participants demonstrates different level of responsibility for mistakes, while resolving a conflict situation; the presence of other students, involved in a conflict, adds the flavor of demonstrational upbringing; the professional position of a teacher has to be primary in taking the initiative in conflict resolution and students' interests must be more important for him/her than his/her own; any mistake of a teacher may lead to new conflicts with new participants.

This article cannot pretend to explore in any depth such vast area as pedagogical conflict, but it seems worth attempting to trail some of the more significant strands in the enormously complex relationships 'student/teacher' because this relationship involves cultures and civilizations, individual human beings, their interaction and their forms of organization, it involves values. This is undoubtedly a very interesting and promising field of investigation and much is expected from the researchers in future.

\section{References}

1. Soroka, I. A. (2015). Psykholohichna profilaktyka konfliktiv u pedahohichnomu kolektyvi vyshchoho navchalnoho zakladu. Kyiv, 256

2. Kozych, I. V. (2009). Formuvannia konfliktolohichnoi kompetentnosti starshoklasnykiv. Naukova skarbnytsia osvity Donechchyny, 1 (4), 66-69.

3. Plakhotna, S. (2014). Konfliktolohichna kompetentnist yak zasib zasvoiennia pozytsii spivrobitnytstva u protsesi vzaiemodii «uchytel-uchni». Problemy pidhotovky suchasnoho vchytelia, 10 (3), 179-183.

4. Aleksandrova, L. Iu., Munshi, A. Iu. (2009). K voprosu o konfliktologicheskoi kompetentnosti spetsialistov. Vestnik CHeboksarskogo kooperativnogo instituta, 1, 180-185.

5. Thomas, K. W. (2002). Introduction to Conflict Management. CPP, 44. Available at: https://www.amazon.com/ Introduction-conflict-management-Improving-performance/dp/B0006RZL4C

6. Runde, C. E., Flangan, T. A. (2006). Becoming a Conflict Competent Leader: How You and Your Organization Can Manage Conflict Effectively. Jossey-Bass.

7. Thomas, K. W., Kilmann, R. H. (1974). Thomas-Kilmann Conflict Mode Instrument. New York: Tuxedo, 16. Available at: https://www.worldcat.org/title/thomas-kilmann-conflict-mode-instrument/oclc/27376637

8. Branitska, T. R. (2013). Formuvannia konfliktolohichnoi kultury maibutnikh fakhivtsiv sotsionomichnoi sfery v Rosii. Teoriia i praktyka upravlinnia sotsialnymy systemamy, 4, 24-30.

9. Antonov, H. V. (2006). Pedahohichni zasady zapobihannia i rozviazannia konfliktiv u navchalno-vykhovnomu seredovyshchi vyshchoho navchalnoho zakladu. Kharkiv, 22.

10. Trukhan, M. A. (2016). Formuvannia hotovnosti maibutnikh sotsialnykh pedahohiv do diialnosti z rozviazannia profesiinykh konfliktiv u zakladakh osvity. Khmelnytskyi, 266.

11. Hlazkova, I. Ya. (2015). Stratehiia zapobihannia konfliktam subiektiv navchalnoho protsesu VNZ. Visnyk Dnipropetrovskoho un-tu imeni Alfreda Nobelia. Seriia: «Pedahohika i psykholohiia». Pedahohichni nauky, 1 (9), 210-215.

12. Karmina, A. S. (Ed.) (1999). Konfliktologiia. Sankt-Peterburg: Izdatelstvo «Lan», 448.

13. Bashkin, M. V. (2014). Konfliktnaia kompetentnost. Iaroslavl: IArGU, 72.

14. Hirnyk, A. M. (2010). Osnovy konfliktolohii. Kyiv: Vydavnychyi dim «Kyievo-Mohylianska akademiia», 222.

15. Volkova, N. P. (2006). Profesiino-pedahohichna komunikatsiia. Kyiv: VTs «Akademiia», 256.

16. Golovanova, I. I. (2011). Metodika upravleniia konfliktami. Kazan: TSentr innovatsionnykh tekhnologii, 79. $\operatorname{grad}, 252$

17. Krishbaum, E. I. (1986). Psikhologo-pedagogicheskii analiz konfliktnykh situatsii v pedagogicheskom protsesse. Lenin-

18. Pidbutska, N. V. (2010). Osoblyvosti konfliktiv u navchalno-vykhovnomu protsesi vyshchykh navchalnykh zakladiv. Naukovyi visnyk MDU imeni V. O. Sukhomlynskoho. Seriia: Pedahohichni nauky, 1 (31), 143-150.

19. Nikulina, I. V. (2016). Fenomenologiia pedagogicheskikh konfliktov. Vestnik Samarskogo un-ta. Seriia: Istoriia, pedagogika, filosofiia, 82-86.

20. Podoliak, L. H., Yurchenko, V. I. (2006). Psykholohiia vyshchoi shkoly. Kyiv: TOV «Fil-studiia», 320.

21. Bilenka, O. B., Chaikivskyi, T. V. (2013). Sotsialno-pedahohichni konflikty u vyshchomu navchalnomu zakladi prychyny vynyknennia ta shliakhy rozviazannia. Naukovyi visnyk NLTU Ukrainy, 23 (12), 385-389.

22. Dolinska, L. V., Matiash-Zaiats, L. P. (2010). Psikhologiia konfliktu. Kyiv: Karavela, 304.

23. Borisova, E. S. (2017). Problema konfliktologicheskoi kompetentnosti v prostranstve obscheobrazovatelnoi organizatsii. Izvestiia Samarskogo nauchnogo tsentra Rossiiskoi akademii nauk. Seriia: Sotsialnye, gumanitarnye, mediko-biologicheskie nauki, 2 (19), $28-32$.

Received date 05.08.2020

Accepted date 17.09.2020

Published date 30.09.2020

Ganna Polishchuk, PhD, Associate Professor, Department of English Language and its Teaching Methods, State Higher Educational Institution «Volodymyr Vynnychenko Central Ukrainian State Pedagogical University», Shevchenko str., 1, Kropyvnytskyi, Ukraine, 25006

E-mail: lopotova@ukr.net 